\title{
Habitat dan Keragaman Tumbuhan Pakan bagi Tapir (Tapirus indicus), Kijang (Muntiacus muncak) dan Kukang (Nycticebus coucang) di Kawasan Gunung Tujuh, Taman Nasional Kerinci Seblat, Jambi
}

\author{
W. Rosa Farida ${ }^{1)}$, Wirdateti ${ }^{1)}$, H. Dahruddin ${ }^{1)}$, dan G. Sumaatmadja ${ }^{2)}$ \\ ${ }^{1)}$ Bidang Zoologi, Pusat Penelitian Biologi-LIPI, Cibinong \\ ${ }^{2}$ Bidang Botani, Pusat Penelitian Biologi-LIPI, Bogor
}

\begin{abstract}
Research on the habitat and the diversity of feed plants of tapir (Tapirus indicus), barking deer (Muntiacus muncak) and slow loris (Nycticebus coucang) have been conducted at Gunung Tujuh, Kerinci Seblat National Park, Jambi. Survey was carried out by visiting places where tapir, barking deer, and slow loris are usually seen and taking collecting herbarium plant specimen of those animals'feed. The habitat of tapir is in region of Gunung Tujuh forest until the altitude of $2020 \mathrm{~m}$ asl. The habitat of barking deer in Gunung Tujuh forest and prefers dense bushes at the edges of forest until the altitude of $1620 \mathrm{~m}$ asl. and the habitat of slow loris in low region of forest. This research found 38 species grouped in 25 families of forest plants as feed resources for tapir, barking deer and slow loris.
\end{abstract}

Key words: Tapirus indicus, Muntiacus muncak, Nycticebus coucang, habitat, feed plants, Kerinci Seblat National Park

\section{Pendahuluan}

Taman Nasional Kerinci Seblat (TNKS) secara ekologis merupakan kawasan pelestarian alam yang memiliki ekosistem asli dan cukup lengkap, yaitu dimulai dari ekosistem hutan hujan dataran rendah sampai ekosistem sub alpin serta beberapa ekosistem khas lainnya, seperti lahan basah dataran tinggi (rawa gambut, rawa air tawar, dan danau).

Kawasan TNKS secara geografis terletak diantara $100^{\circ} 31^{\prime} 18^{\prime \prime}-102^{\circ}$ 44' 1" BT dan $1^{\circ} 7^{\prime} 13^{\prime \prime}-3^{\circ} 26^{\prime} 14^{\prime \prime}$ LS. Secara administrasi kawasan TNKS masuk ke dalam empat wilayah propinsi, yaitu Jambi, Bengkulu, Sumatera Barat, dan Sumatera Selatan.
Luas kawasan TNKS yang termasuk dalam propinsi Jambi adalah 418.051 ha. Di kawasan ini terdapat beberapa obyek wisata yaitu puncak Gunung Kerinci yang merupakan puncak tertinggi di Indonesia (3.805 m dpl), danau dan air terjun Gunung Tujuh, Gunung Lumut, air terjun Telun Berasap, Goa Kasah, danau Belibis, rawa Ladeh Panjang, dan rawa Bento.

Kawasan Gunung Tujuh merupakan salah satu sentra keanekaragaman hayati TNKS yang di dalamnya terdapat berbagai jenis tumbuhan dan satwa serta fenomena alam yang indah. Danau Gunung Tujuh dapat dicapai dengan berjalan kaki menyusuri jalan setapak yang menanjak selama \pm 3 jam melalui 
dusun terdekat yaitu dusun Ulu Jernih-Pelompek dari pos jaga hingga danau berjarak sekitar \pm 7 $\mathrm{km}$.

Danau Gunung Tujuh merupakan danau yang terbentuk dari bekas letusan salah sebuah kepundan dimasa lampau. Danau ini berada pada ketinggian $1.960 \mathrm{~m}$ dpl, luasnya $\pm 12 \mathrm{~km}^{2}$ berukuran panjang $\pm 4,5$ $\mathrm{km}$ dan lebar $\pm 3 \mathrm{~km}$ dan dikelilingi oleh tujuh buah gunung dengan puncak tertinggi yaitu Gunung Tujuh $2.732 \mathrm{~m}$ dpl. Keadaan alamnya yang indah dan unik kemudian digunakan sebagai nama dari danau dan kelompok hutan disekitarnya.

Di kawasan hutan Gunung Tujuh saat ini telah terjadi pula perambahan hutan dan pembukaan lahan-lahan pertanian. Kegiatan tersebut tentu saja akan mengancam daerah perlindungan, karena terbukti banyak dijumpai penebangan liar di dalam kawasan Cagar Alam. Dikhawatirkan keberadaan satwa di hutan Cagar Alam akan ikut terancam, demikian juga dengan ketersediaan tumbuhan hutan sebagai sumber pakannya. Menurut informasi masyarakat lokal, jenis mamalia dilindungi yang berada dikawasan hutan Gunung tujuh antara lain harimau sumatera (Panthera tigris sumatrensis), macan dahan (Neofelis nebulosa), beruang madu (Helarctos malayanus), tapir (Tapirus indicus), rusa sambar (Cervus unicolor), kancil (Tragulus javanicus), kijang (Muntiacus muntjak), kelinci hutan (Nesolagus sumatranus), musang hamaker (Mustela hamakeri), dan berbagai jenis primata seperti unko (Hylobates agilis), siamang (Symphalangus syndactylus), simpai (Presbytis melalophos), lutung hitam (Presbytis cristata), kukang (Nycticebus coucang), beruk (Macaca nemes- trina), dan kera ekor panjang (Macaca fasciculalis). Sebagian mamalia tersebut adalah satwa langka yang saat ini statusnya terancam punah, tercantum dalam Appendix I (CITES), dan di Indonesia sejak tahun 1931 tercatat sebagai satwa yang dilindungi undang - undang (Anonimous, 1996).

Jejak-jejak kaki tapir, bekas goresan tanduk rusa dan kijang pada batang pohon, bekas cakaran beruang madu yang melubangi batang pohon, dan munculnya berbagai jenis primata sering dijumpai di kawasan pendakian menuju danau Gunung Tujuh.

Keutuhan habitat dan kelestarian jenis tumbuhan hutan sebagai sumber pakan bagi kijang, tapir, dan kukang yang merupakan satwa yang di fokuskan dalam penelitian ini perlu dijaga, guna menjamin kelangsungan hidup satwa-satwa tersebut di habitat aslinya (in situ).

Tujuan dari penelitian ini adalah untuk mengetahui tentang kondisi habitat dan ketersediaan jenis-jenis tumbuhan pakan bagi kijang, tapir, dan kukang di wilayah tersebut.

\section{Materi dan Metode}

Penelitian langsung ke daerah penyebaran habitat kijang, tapir, dan kukang di kawasan Gunung Tujuh, Taman Nasional Kerinci Seblat, Jambi, telah dilakukan pada bulan Juni 2003. Pengamatan kondisi habitat kijang, tapir, dan kukang dan pengumpulan jenis-jenis tumbuhan hutan sebagai sumber pakannya dilakukan berdasarkan metoda jelajah dengan mengikuti masyarakat /pemburu lokal ke lokasi-lokasi seringnya dijumpai tapir, kijang, dan kukang. Setiap pohon yang dijumpai sebagai pakan satwa-satwa tersebut dilakukan pengukuran diameter 
batang setinggi dada dan tinggi pohon, kemudian diambil contoh batang, ranting, dan daun, serta bunga dan buah (bila ada). Sampel tumbuhan tersebut disusun dengan berlapis kertas koran bekas dan dibasahi dengan spritus sebagai pengawet untuk selanjutnya diidentifikasi di Herbarium Bogoriense /Bidang Botani, Pusat Penelitian Biologi-LIPI, Bogor.

Koleksi sampel tumbuhan pakan berupa daun, bunga, atau buah dikumpulkan sebanyak mungkin dan dimasukkan ke dalam kantong plastik. Di base camp sampel dikeringkan dan dijemur di bawah sinar matahari hingga dicapai berat kering matahari. Untuk jenis buahbuahan dilakukan dipotong kecilkecil guna mempercepat pengeringan. Di Laboratorium Nutrisi, Bidang Zoologi, Puslit Biologi LIPI Cibinong, sampel daun-daunan kering kemudian dikeringkan lagi dalam oven selama 12 jam dan untuk jenis buah-buahan selama 18 jam pada suhu $60^{\circ} \mathrm{C}$, selanjutnya digiling halus untuk dilakukan analisa kandungan nutrisi (analisa proksimat) berdasarkan metoda Harris (1970).

\section{Hasil dan Pembahasan}

Selama pengamatan di lokasi sepanjang jalur pendakian di kawasan hutan Gunung Tujuh ditemukan beberapa bekas jejak kaki tapir pada ketinggian $2020 \mathrm{~m}$ dpl dan di hutan seberang danau Gunung Tujuh yaitu di Bukit Julang Gedang (1935 m dpl) ditemukan bekas-bekas tempat tidur/istirahat/habitat tapir yaitu disela-sela banir beberapa pohon besar seperti pohon kayu aro (Ficus sp.).
Pada serasah lantai hutan $\pm 50 \mathrm{~m}$ dari pinggiran danau ditemukan juga jejak-jejak kaki tapir, diduga merupakan jalan tapir menuju danau untuk tujuan minum ke danau. Di lokasi Bukit Julang Gedang, pada pohon medang kuning (Litsea sp) ditemukan bekas garukan tanduk kijang atau rusa sebagai salah satu bukti keberadaan satwa tersebut. Selama pengamatan tidak pernah secara langsung melihat tapir, kijang, atau kukang. Pada lokasi jalur pendakian (2020 m dpl) setelah ditelusuri berdasarkan bekas-bekas jejak kaki tapir ditemukan juga jalur yang sering menjadi lintasan tapir. Jejak tapir di hutan mudah dikenali karena jejak kakinya mirip badak dengan perbedaan kukunya lebih panjang dan lebih sempit (Lekagul dan Mc Neely, 1977). Menurut informasi polisi hutan yang menemani tim peneliti selama eksplorasi bahwa bila kita menyusuri terus lintasan jalan tapir tersebut maka akan sampai di punggung Gunung Hulu Sangir pada ketinggian $1800 \mathrm{~m}$ dpl terdapat habitat tapir yaitu disela-sela banir pohon besar, bahkan banyak ditemukan tumpukan kotoran /feces tapir. Sebagaimana dilaporkan oleh MacKinnon (1984) bahwa habitat tapir adalah hutan hujan tropis dengan ketinggian $300-2000 \mathrm{~m}$ dpl. Di Sumatera tapir tersebar di beberapa tipe habitat seperti hutan rawa, hutan gambut, hutan dataran rendah, hutan pegunungan bawah hingga hutan pegunungan tinggi. Dilaporkan oleh Blouch (1984), kehidupan tapir saat ini di habitat aslinya di wilayah Taman Nasional Kerinci Seblat dan sekitarnya sangat memprihatinkan, akibat perambahan hutan, penebangan liar, pembukan hutan untuk perkebunan dan pemukiman yang menyebabkan rusaknya habitat tapir. 
Tabel 1. Posisi Lokasi Penelitian di Kawasan Hutan Gunung Tujuh, TNKS, Jambi

\begin{tabular}{|c|c|c|c|c|c|c|c|c|c|}
\hline $\begin{array}{l}\text { LA } \\
\text { TD }\end{array}$ & $\begin{array}{l}\text { LA } \\
\text { TM }\end{array}$ & $\begin{array}{l}\text { LA } \\
\text { TS }\end{array}$ & $\begin{array}{l}\text { DIR } \\
\text { LAT }\end{array}$ & $\begin{array}{l}\text { LONG } \\
\text { D }\end{array}$ & $\begin{array}{l}\text { LONG } \\
\mathrm{M}\end{array}$ & LONG & $\begin{array}{l}\text { DIRL } \\
\text { ON }\end{array}$ & $\begin{array}{l}\text { ALT } \\
(\mathrm{m} \mathrm{dpl})\end{array}$ & LOKASI \\
\hline 2 & 03 & 19.3 & $\mathrm{~S}$ & 101 & 23 & 08.5 & $\mathrm{E}$ & 740 & $\begin{array}{l}\text { Kantor TNKS, Sungai } \\
\text { Penuh }\end{array}$ \\
\hline 1 & 54 & 52.3 & $\mathrm{~S}$ & 101 & 18 & 11.2 & $\mathrm{E}$ & 1000 & Simpang Ds. Siulak Deras \\
\hline 1 & 49 & 20.9 & $S$ & 101 & 15 & 24.2 & $\mathrm{E}$ & 1380 & $\begin{array}{l}\text { PTP Nusantara VI, Kebun } \\
\text { teh Kayu Aro }\end{array}$ \\
\hline 1 & 42 & 51.9 & $S$ & 101 & 20 & 42.9 & $\mathrm{E}$ & 1390 & $\begin{array}{l}\text { Simpang Pelompek, Kec. } \\
\text { Kayu Aro }\end{array}$ \\
\hline 1 & 43 & 07.6 & $\mathrm{~S}$ & 101 & 21 & 40.2 & $\mathrm{E}$ & 1420 & $\begin{array}{l}\text { Dusun Ulu Jernih, Desa } \\
\text { Pesisir Bukit (Base camp) }\end{array}$ \\
\hline 1 & 42 & 48.0 & $S$ & 101 & 21 & 58.1 & $\mathrm{E}$ & 1430 & $\begin{array}{l}\text { Pintu gerbang TNKS, } \\
\text { koleksi pakan kukang } \\
\text { (kayu sikumbang), pakan } \\
\text { tapir (buah asam kandis) }\end{array}$ \\
\hline 1 & 42 & 49.1 & $\mathrm{~S}$ & 101 & 22 & 03.8 & $\mathrm{E}$ & 1440 & $\begin{array}{l}\text { Jalur pendakian lama G. } \\
\text { Tujuh, koleksi pakan } \\
\text { primata dan tupai (setun) }\end{array}$ \\
\hline 1 & 42 & 43.2 & $S$ & 101 & 22 & 23.4 & $\mathrm{E}$ & 1450 & $\begin{array}{l}\text { Koleksi pakan tapir dan } \\
\text { kijang (pua, umput } \\
\text { belando, umput sepidin, } \\
\text { dan umput telebung)) }\end{array}$ \\
\hline$*)$ & $*)$ & $*)$ & $S$ & $*)$ & $*)$ & *) & E & 1460 & $\begin{array}{l}\text { Koleksi pakan kijang dan } \\
\text { kukang (seting, daun cabe } \\
\text { keriting, jeluang) }\end{array}$ \\
\hline$*)$ & $*)$ & $*)$ & $S$ & $*)$ & *) & $*)$ & E & 1470 & $\begin{array}{l}\text { Koleksi pakan tapir dan } \\
\text { kijang (capu angin) }\end{array}$ \\
\hline$*)$ & $*)$ & $*)$ & $S$ & $*)$ & *) & *) & E & 1520 & $\begin{array}{l}\text { Shelter I jalur pendakian } \\
\text { lama G. Tujuh }\end{array}$ \\
\hline$*)$ & $*)$ & $*)$ & $S$ & $*)$ & *) & *) & E & 1620 & $\begin{array}{l}\text { Koleksi pakan tapir dan } \\
\text { kijang, ditemukan habitat } \\
\text { kijang di bawah pohon } \\
\text { kayu aro }\end{array}$ \\
\hline 1 & 42 & 43.2 & $S$ & 101 & 22 & 23.4 & E & 1720 & $\begin{array}{l}\text { Terlihat } 4 \text { ekor tupai di } \\
\text { pohon langsat kero }\end{array}$ \\
\hline$*)$ & $*)$ & $*)$ & $S$ & $*)$ & *) & *) & E & 1800 & $\begin{array}{l}\text { Koleksi pakan tapir (kayu } \\
\text { asam, inai rimbo, buah } \\
\text { akar gitan) }\end{array}$ \\
\hline 1 & 42 & 21.0 & $S$ & 101 & 23 & 24.5 & E & 2010 & $\begin{array}{l}\text { Lintasan tempat lewatnya } \\
\text { tapir ke arah G. Sangir }\end{array}$ \\
\hline 1 & 42 & 21.2 & $S$ & 101 & 23 & 24.9 & E & 2020 & $\begin{array}{l}\text { Ditemukan bekas jejak } \\
\text { kaki tapir, shelter puncak } \\
\text { pendakian jalur baru }\end{array}$ \\
\hline 1 & 42 & 15.4 & $S$ & 101 & 22 & 58.7 & E & 1935 & Tepi/muara danau G. tujuh \\
\hline 1 & 42 & 68.5 & $S$ & 101 & 22 & 22.0 & E & 1450 & $\begin{array}{l}\text { Koleksi pakan tapir (umput } \\
\text { bento), jalur baru } \\
\text { pendakian G. Tujuh }\end{array}$ \\
\hline 1 & 42 & 61.3 & $S$ & 101 & 22 & 24.9 & E & 1500 & $\begin{array}{l}\text { Koleksi pakan tapir dan } \\
\text { kijang (kayu suluh) }\end{array}$ \\
\hline 1 & 42 & 34.2 & $S$ & 101 & 22 & 50.9 & E & 1920 & $\begin{array}{l}\text { Ditemukan bekas cakaran } \\
\text { beruang madu } \\
\text { (membolongi kayu ubi), } \\
\text { jalur baru pendakian G.. } \\
\text { Tujuh }\end{array}$ \\
\hline & 42 & 48.9 & $S$ & 101 & 23 & 16.7 & E & 2010 & $\begin{array}{l}\text { Ditemukan bekas lintasan } \\
\text { beruang madu pada jalur } \\
\text { baru pendakian G. Tujuh }\end{array}$ \\
\hline 1 & 42 & 4.3.6 & $S$ & 101 & 23 & 29.1 & E & 2045 & $\begin{array}{l}\text { Shelter puncak pendakian } \\
\text { jalur lama G. tujuh terletak }\end{array}$ \\
\hline
\end{tabular}




\begin{tabular}{|c|c|c|c|c|c|c|c|c|l|}
\hline$*)$ & $*)$ & $*)$ & $\mathrm{S}$ & $*)$ & $*)$ & $*)$ & $\mathrm{E}$ & 1945 & $\begin{array}{l}\text { antara G. Hulu Sangir dan } \\
\text { G. Manduran }\end{array}$ \\
\hline 1 & 41 & 45.9 & $\mathrm{~S}$ & 101 & 24 & 17.1 & $\mathrm{E}$ & 1935 & $\begin{array}{l}\text { koleksi pakan tapir (umput } \\
\text { kudo, Bukit juhung } \\
\text { gedang di seberang danau } \\
\text { G. tujuh }\end{array}$ \\
\hline 1 & 42 & $61 . .3$ & $\mathrm{~S}$ & 101 & 22 & 24.9 & $\mathrm{E}$ & 1500 & $\begin{array}{l}\text { Ditemukan bekas jejak } \\
\text { tapir, bekas tapir tidur di } \\
\text { banir kayu aro, Bukit } \\
\text { juhung gedang di seberang } \\
\text { danau G. tujuh (3.4 km } \\
\text { dari muara danau) }\end{array}$ \\
\hline 1 & 42 & 85.8 & $\mathrm{~S}$ & 101 & 22 & 11.6 & $\mathrm{E}$ & 1430 & $\begin{array}{l}\text { Menara pengintai jalur } \\
\text { baru pendakian G. Tujuh }\end{array}$ \\
\hline
\end{tabular}

*) GPS tidak memperlihatkan posisi koordinat di lokasi tersebut karena rapatnya kanopi

Tabel 2. Daftar Tumbuhan Hutan yang Disukai Kukang sebagai Tempat Bersarang (Habitat)

\begin{tabular}{|l|l|l|c|c|}
\hline \multicolumn{1}{|c|}{ SUKU } & \multicolumn{1}{|c|}{ JENIS } & \multicolumn{1}{c|}{ NAMA LOKAL } & $\begin{array}{c}\text { TINGGI } \\
(\mathrm{m})\end{array}$ & $\begin{array}{c}\text { KETINGGIAN } \\
\text { SARANG (m) }\end{array}$ \\
\hline Euphorbiaceae & Prunus sp. & Sikumbang & 35 & $12-25$ \\
\hline Fagaceae & $\begin{array}{l}\text { Quercus omalocos } \\
\text { Korth. }\end{array}$ & Empening putih & 45 & $15-25$ \\
\hline & C. acuminastissima & Empening merah & 47 & $15-26$ \\
\hline & $\begin{array}{l}\text { Castanopsis } \\
\text { tunggurut }\end{array}$ & Empening oman & 45 & $15-25$ \\
\hline Lauraceae & $\begin{array}{l}\text { Cinnamomum } \\
\text { burmanni }\end{array}$ & Kayu manih & 10 & 8 \\
\hline Urticaceae & - & Kayu menarung & 27 & $15-20$ \\
\hline
\end{tabular}

Bekas garukan kuku beruang madu melubangi batang pohon yang diduga ada sumber madunya ditemukan pada pohon kayu ubi (Syzigium sp.) di jalur lama pendakian (1760 m dpl) dan pada ketinggian $2010 \mathrm{~m}$ dpl terdapat bekas lintasan beruang madu.

Selain bukti-bukti keberadaan tapir, bekas guratan tanduk kijang dan rusa pada batang di kawasan yang disurvai, diperoleh juga informasi dari penduduk lokal bahwa kijang lebih menyukai habitat di semak-semak pinggiran hutan dan lebih sering terlihat pada sore hari.

Informasi dari pembantu lapangan yang pernah mendampingi seorang peneliti asing yang meneliti dengan mempergunakan kamera jebakan (camera trap) terekam beberapa jenis mamalia dilindungi yang terdapat di kawasan hutan gunung Tujuh seperti macan dahan, macan bulu, tenuk/tapir, kijang, beruang madu, landak, trenggiling, dan babi hutan. 
Dari hasil wawancara dengan penduduk lokal bahwa habitat/sarang kukang (Nycticebus coucang) sering terlihat pada pohon empening (Castanopsis sp.), kayu manis (Cinnamomum burmanii), sikumbang (Prunus sp.), dan kayu menarung (suku Urticaceae) (Tabel 2). Tinggi Pohon-pohon tempat kukang bersarang berkisar antara $10-47 \mathrm{~m}$ dan berdaun lebat. Menurut Yasuma dan Alikondra (1990), habitat yang disukai kukang adalah hutan hujan tropis yang memiliki sumber air yang banyak, sehingga mendukung ketersediaan pakan, sedangkan di hutanhutan sekunder kukang menyukai hidup di pohon-pohon yang berukuran kecil dan sedang. Dalam pengamatan ini diketahui kadangkadang kukang beristirahat (bersarang) pada tanaman inang yang tumbuh melekat di pohon-pohon tersebut seperti tumbuhan kadaka (Asplenium sp.). Hal ini dimungkinkan karena kukang merasa lebih aman dan kadang kala pada tumbuhan kadaka sering terdapat telur atau anak burung, cecak pohon, dan mamalia kecil lainnya yang merupakan sumber pakan kukang selain buah-buahan hutan.

Tumbuhan hutan sebagai sumber pakan kijang, tapir, dan kukang yang teridentifikasi selama survai berjumlah 38 jenis yang tergolong kedalam 25 suku (Tabel 3). Dari Tabel 3 terlihat 12 jenis tumbuhan yang dipilih baik oleh kijang dan tapir sebagai sumber pakannya, dan hanya 1 jenis tumbuhan yang dimakan kijang, 6 jenis tumbuhan yang dimakan oleh tapir, 4 jenis tumbuhan dimakan baik oleh tapir juga kukang, 14 jenis tumbuhan dimakan oleh kukang, dan hanya 1 jenis tumbuhan yang dimakan baik oleh kijang, tapir, maupun kukang. Tapir dan Kijang lebih banyak memilih pakan jenis rerumputan dan dedaunan, sedangkan kukang lebih banyak memilih jenis buah-buahan. Di habitat aslinya tapir mengkonsumsi rerumputan, daun-daun muda, tunas, rantingranting muda, tumbuhan air, dan buah-buah tumbuhan perdu rendah (Williams, 1980), dan tapir juga menyukai jahe dan buah-buahan termasuk durian. Kijang yang tergolong satwa peranggas, tetapi mengkonsumsi juga banyak rerumputan, selain memakan dedaunan pohon, semak, tumbuhan herba, dan buah - buahan hutan (Lekagul dan Mc Neely, 1977). Dalam pengamatan kali ini tidak diperoleh informasi tentang alang-alang muda yang dimakan oleh kijang, sebagaimana hasil penelitian Farida et al (2002) di Taman Nasional Gunung Halimun, Jawa Barat, bahwa kijang menyukai jenis-jenis rumput dan alang-alang muda. Hal ini diduga karena banyaknya gangguan perburuan oleh penduduk dan dekatnya wilayah yang ditumbuhi alang-alang tersebut dengan perkampungan Pesisir Bukit, sehingga kijang enggan turun ke padang alang-alang tersebut. Kijang berbeda dengan hewan ruminansia lainnya, karena kijang tidak begitu menyukai rumput-rumputan fase vegetatif, tetapi lebih menyukai tunas-tunas muda yang baru tumbuh di pinggiran hutan. Sifat memakan tunas baru tumbuhan di lahan habis terbakar, erat kaitannya dengan upaya pemenuhan mineral, khususnya bagi kijang atau rusa pejantan yang sedang tumbuh ranggah (Semiadi, 1998).

Pada pengamatan kukang di lokasi hutan kawasan Gunung Tujuh, hanya pakan tumbuhan saja yang dikoleksi, sedangkan jenis pakan asal hewan tidak diamati, karena perlu 
waktu pengamatan yang lebih lama di dalam hutan untuk memastikan jenis hewan kecil yang dikonsumsi oleh kukang, sebagaimana yang dilaporkan oleh Napier dan Napier (1967), di habitat aslinya kukang biasa mengkonsumsi berbagai jenis tumbuhan pakan seperti buah-buahan lunak, biji-bijian, dedaunan, tetapi juga memakan pakan asal hewan seperti serangga, telur burung, kadal, dan mamalia kecil. Supriatna dan Wahyono (2000) menyatakan bahwa kukang memakan buah-buahan berserat sekitar $50 \%$, selain itu kukang juga memakan berbagai jenis binatang sekitar $40 \quad \%$ seperti serangga, moluska, kadal, kadangkadang memakan juga telur burung dan $10 \%$ getah. Hewan ini juga sering mengkonsumsi biji-bijian dari biji polong (leguminosae), termasuk buah atau biji coklat. Dari hasil penelitian Wirdateti et al. (2002) melaporkan bahwa kukang di alam juga menjilati nira dari pohon aren dan getah bunga tumbuhan hutan.

Hasil analisa kandungan nutrisi tumbuhan pakan sebagai sumber pakan kijang, tapir, dan kukang tertera pada Tabel 4. Dari 38 jenis tumbuhan yang tercatat sebagai sumber pakan, hanya 19 jenis tumbuhan pakan yang dapat dianalisa kandungan nutrisinya, karena jenis lainnya terutama jenis buah-buahan banyak yang sedang tidak musim saat penelitian berlangsung.
Nilai nutrisi dari bagian tumbuhan hutan yang menjadi pilihan kuskus sebagai pakan sangat bervariasi. Kandungan kadar abu (mineral) tumbuhan pakan antara $1,93 \%$ yang terendah dan $21,05 \%$ yang tertinggi, dengan rataan nilai $10,67 \%(\mathrm{SD}=5,25)$; protein antara $2,36 \%-33,86 \%$, rataan nilai 14,45 $\%(\mathrm{SD}=8,93)$; lemak antara $0,31 \%$ $5,29 \%$, rataan nilai $1,16 \%(\mathrm{SD}=$ $1,25)$; serat kasar antara 8,25\% $50,05 \%$, rataan nilai $20,20 \%(\mathrm{SD}=$ 15,04); dan nilai energi antara 3101 $\mathrm{kal} / \mathrm{g}$ - $4548 \mathrm{kal} / \mathrm{g}$, rataan nilai 3250,47 (SD = 1438,91). Dari hasil analisa kandungan nutrisi, terlihat tumbuhan pakan yang dipilih tapir, kijang, dan kukang sebagai sumber pakannya, mempunyai rentang nilai yang beragam untuk kandungan protein dan serat kasar. Analisa nutrisi tumbuhan pakan perlu dilakukan, guna mencarikan pakan alternatif yang nilai gizinya mendekati nilai gizi tumbuhan pakan di habitat aslinya guna mempermudah dalam penyediaan pakan alternatif bila kijang, tapir, maupun kukang ditangkarkan baik untuk tujuan penelitian, konservasi, maupun budidaya. Seperti dikemukakan oleh Thohari (1987), untuk mendukung kehidupan satwa liar diperlukan habitat yang cocok, lingkungan penangkaran disesuaikan dengan habitat aslinya, sehingga nyaman sebagai tempat tinggal, tempat berlindung, tempat istirahat, dan tersedia pakan sesuai dengan kebutuhan. 
Tabel 3. Daftar Tumbuhan Pakan Kijang, Tapir, dan Kukang di Kawasan Hutan Gunung Tujuh TNKS, Jambi

\begin{tabular}{|c|c|c|c|c|c|c|}
\hline No & SUKU & NAMA ILMIAH & $\begin{array}{l}\text { NAMA } \\
\text { LOKAL }\end{array}$ & $\begin{array}{c}\text { BAGIAN } \\
\text { YANG } \\
\text { DIMA- } \\
\text { KAN }\end{array}$ & $\begin{array}{l}\text { DIMA- } \\
\text { KAN } \\
\text { OLEH }\end{array}$ & $\begin{array}{c}\text { JENIS } \\
\text { TUMBUH- } \\
\text { AN }\end{array}$ \\
\hline 1. & Agavaceae & 1. Cordyline fructi-cosa & Jeluang & $\begin{array}{l}\text { Daun } \\
\text { muda }\end{array}$ & $\begin{array}{c}\text { Kijang, } \\
\text { Tapir }\end{array}$ & Perdu \\
\hline 2. & Amaranthaceae & 2. Celosia cristata & $\begin{array}{l}\text { Bunga } \\
\text { dayung }\end{array}$ & Buah & Tapir & Perdu \\
\hline 3. & Anacardiaceae & 3. Mangifera indica & Pauh & Buah & Kukang & $\begin{array}{l}\text { Pohon } \\
\text { besar }\end{array}$ \\
\hline 4. & Anonaceae & 4. - & $\begin{array}{l}\text { Kayu aka } \\
\text { (buah besar } \\
\text { merah) }\end{array}$ & Buah & Tapir & Liana \\
\hline 5. & Asteraceae & $\begin{array}{l}\text { 5. Erechites } \\
\text { valerianifolia }\end{array}$ & Capu angin & Daun & $\begin{array}{c}\text { Kijang, } \\
\text { tapir }\end{array}$ & Perdu \\
\hline 6. & Clusiaceae & 6. Garcinia parvifolia & $\begin{array}{l}\text { Asam } \\
\text { kandih }\end{array}$ & Buah & Tapir & Pohon \\
\hline 7. & Cyperaceae & 7. Cyperus spelata & $\begin{array}{l}\text { Umput } \\
\text { sepiding }\end{array}$ & $\begin{array}{l}\text { Daun + } \\
\text { batang }\end{array}$ & $\begin{array}{c}\text { Kijang, } \\
\text { tapir }\end{array}$ & Rumput \\
\hline 8. & Euphorbiaceae & 8. Omalanthus populneus & Melu & $\begin{array}{l}\text { Daun } \\
\text { muda }\end{array}$ & Kukang & $\begin{array}{l}\text { Pohon } \\
\text { sedang }\end{array}$ \\
\hline & & 9. Prunus sp. & Sikumbang & $\begin{array}{l}\text { Daun } \\
\text { muda }\end{array}$ & Kukang & Pohon \\
\hline 9. & Fabaceae & 10.Leucaena eucocephala & Seting & $\begin{array}{c}\text { Daun } \\
\text { muda, } \\
\text { dan buah }\end{array}$ & $\begin{array}{c}\text { Kijang, } \\
\text { Tapir, } \\
\text { Kukang }\end{array}$ & Pohon \\
\hline 10. & Fagaceae & 11. Quercus omalocos & Semuluh & Buah & Kukang & Pohon \\
\hline 11. & Lauraceae & $\begin{array}{l}\text { 12.Cinnamomum } \\
\text { kulilawan }\end{array}$ & $\begin{array}{l}\text { Kayu } \\
\text { lawang }\end{array}$ & $\begin{array}{l}\text { Daun } \\
\text { muda }\end{array}$ & Kukang & $\begin{array}{l}\text { Pohon } \\
\text { besar }\end{array}$ \\
\hline \multirow[t]{2}{*}{12.} & Meliaceae & 13. Aglaia $\mathrm{sp}$. & Langsat kro & $\begin{array}{l}\text { Daun } \\
\text { muda }\end{array}$ & Kukang & Pohon \\
\hline & & 14. Toona seruni & Surian & $\begin{array}{l}\text { Pucuk } \\
\text { daun }\end{array}$ & Kukang & Pohon \\
\hline \multirow[t]{4}{*}{13.} & Moraceae & 15. Ficus acantophylla & Akar gitan & Buah & Tapir & Pemanjat \\
\hline & & 16. Ficus variegata & Aro kaen & Buah & $\begin{array}{c}\text { Kijang, } \\
\text { tapir }\end{array}$ & $\begin{array}{c}\text { Pohon } \\
\text { besar }\end{array}$ \\
\hline & & 17. Ficus racemosa & Aro tumpuk & Buah & $\begin{array}{c}\text { Kijang, } \\
\text { tapir }\end{array}$ & $\begin{array}{c}\text { Pohon } \\
\text { besar }\end{array}$ \\
\hline & & 18. Ficus sp. & Aro kesik & Buah & Kukang & $\begin{array}{c}\text { Pohon } \\
\text { besar }\end{array}$ \\
\hline 14. & Musaceae & 19. Musa acuminata & $\begin{array}{l}\text { Pisang } \\
\text { rotan }\end{array}$ & $\begin{array}{l}\text { Buah, } \\
\text { Umbut }\end{array}$ & $\begin{array}{c}\text { Tapir, } \\
\text { kukang }\end{array}$ & Terna \\
\hline \multirow[t]{2}{*}{15.} & Myrsinaceae & 20. Ardisia crispa & Kayu asam & $\begin{array}{l}\text { Daun } \\
\text { muda }\end{array}$ & Tapir & Perdu \\
\hline & & 21. - & $\begin{array}{l}\text { Kayu aka } \\
\text { buah kecil }\end{array}$ & Buah & Tapir & Perdu \\
\hline \multirow[t]{2}{*}{16.} & Myrtaceae & 22. Eugenia cuprea & Kayu luluh & Buah & Kukang & $\begin{array}{l}\text { Pohon } \\
\text { sedang }\end{array}$ \\
\hline & & 23. Eugenia opaca & $\begin{array}{l}\text { Jambu } \\
\text { arang }\end{array}$ & Buah & $\begin{array}{c}\text { Kijang, } \\
\text { Tapir }\end{array}$ & $\begin{array}{c}\text { Pohon } \\
\text { besar }\end{array}$ \\
\hline \multirow[t]{2}{*}{17.} & Pasifloraceae & 24. Pasiflora regularis & Markisa & Buah & Kukang & Pemanjat \\
\hline & & 25. Pasiflora sp. & $\begin{array}{l}\text { Manggis } \\
\text { burung }\end{array}$ & Buah & Kukang & Pemanjat \\
\hline 18. & Poaceae & 26. Drymaria sp. & $\begin{array}{l}\text { Umput } \\
\text { bento }\end{array}$ & $\begin{array}{l}\text { Daun }+ \\
\text { batang }\end{array}$ & $\begin{array}{c}\text { Kijang, } \\
\text { Tapir }\end{array}$ & Rumput \\
\hline
\end{tabular}




\begin{tabular}{|c|c|c|c|c|c|c|}
\hline & & $\begin{array}{l}\text { 27. } \begin{array}{c}\text { Panicum palmi- } \\
\text { folium }\end{array} \\
\end{array}$ & $\begin{array}{l}\text { Umput } \\
\text { telebung }\end{array}$ & $\begin{array}{l}\text { Daun + } \\
\text { batang }\end{array}$ & $\begin{array}{c}\text { Kijang, } \\
\text { tapir }\end{array}$ & Rumput \\
\hline & & 28. Paspalum cojugatum & $\begin{array}{l}\text { Umput } \\
\text { belando }\end{array}$ & $\begin{array}{c}\text { Daun }+ \\
\text { batang }\end{array}$ & $\begin{array}{c}\text { Kijang, } \\
\text { tapir }\end{array}$ & Rumput \\
\hline 19. & Rhamnaceae & 29. Zyzypus sp. & Kayu suluh & $\begin{array}{c}\text { Pucuk } \\
\text { daun }\end{array}$ & $\begin{array}{c}\text { Kijang, } \\
\text { tapir }\end{array}$ & Perdu \\
\hline 20. & Rubiaceae & 30. Ophiorrhiza sp. & Inai rimbo & Daun & $\begin{array}{c}\text { Kijang, } \\
\text { tapir }\end{array}$ & Perdu \\
\hline \multirow[t]{3}{*}{21.} & Solanaceae & 31. Capsicum annum & $\begin{array}{l}\text { Daun cabe } \\
\text { keriting }\end{array}$ & $\begin{array}{c}\text { Pucuk } \\
\text { daun }\end{array}$ & Kijang & Perdu \\
\hline & & 32. Cypomandra betasea & $\begin{array}{l}\text { Terung } \\
\text { pirus }\end{array}$ & Buah & Kukang & Perdu \\
\hline & & 33. Physalis angulata & Setun & $\begin{array}{c}\text { Daun dan } \\
\text { buah }\end{array}$ & $\begin{array}{l}\text { Tapir, } \\
\text { Kukang }\end{array}$ & Perdu \\
\hline 22. & Ulmaceae & 34. Trema orientalis & Kayu nasi & Buah & Kukang & $\begin{array}{l}\text { Pohon } \\
\text { besar }\end{array}$ \\
\hline \multirow[t]{2}{*}{24.} & Urticaceae & 35. Pilea $\mathrm{sp}$. & $\begin{array}{l}\text { Umput } \\
\text { candi }\end{array}$ & $\begin{array}{c}\text { Pucuk } \\
\text { daun }\end{array}$ & $\begin{array}{c}\text { Kijang, } \\
\text { tapir }\end{array}$ & Perdu \\
\hline & & 36. - & Stungo & $\begin{array}{l}\text { Daun } \\
\text { muda }\end{array}$ & Kukang & $\begin{array}{l}\text { Pohon } \\
\text { sedang }\end{array}$ \\
\hline \multirow[t]{2}{*}{25.} & Zingiberaceae & 37. Amomum aculeatum & Lolo ayam & $\begin{array}{l}\text { Buah dan } \\
\text { umbut }\end{array}$ & $\begin{array}{l}\text { Tapir, } \\
\text { Kukang }\end{array}$ & Perdu \\
\hline & & 38. Amomum coccineum & Pua & Umbut & $\begin{array}{l}\text { Tapir, } \\
\text { Kukang }\end{array}$ & Perdu \\
\hline
\end{tabular}

Tabel 4. Kandungan Nutrisi Tumbuhan Hutan sebagai Pakan Kijang, Tapir dan Kukang yang Berasal dari Kawasan Gunung Tujuh, Taman Nasional Kerinci Seblat.

\begin{tabular}{|c|c|c|c|c|c|c|c|}
\hline \multirow{2}{*}{$\begin{array}{c}\text { No } \\
\text {. }\end{array}$} & \multirow{2}{*}{$\begin{array}{l}\text { Jenis Tumbuhan (Nama } \\
\text { Lokal) }\end{array}$} & BK & $\mathrm{Abu}$ & Protein & Lemak & $\begin{array}{l}\text { Serat } \\
\text { Kasar }\end{array}$ & Energi \\
\hline & & $\%$ & $\%$ & $\%$ & $\%$ & $\%$ & $\mathrm{kal} / \mathrm{g}$ \\
\hline & Daun (+ batang muda) : & & & & & & \\
\hline 1. & Umput belando & 94,08 & 13,65 & 11,54 & 0,84 & 40,19 & 3278 \\
\hline 2. & Umput sepidin & 92,28 & 10,34 & 7,07 & 1,62 & 43,33 & 3788 \\
\hline 3. & Umput telebung & 94,03 & 10,49 & 18,99 & 0,66 & 28,03 & 3696 \\
\hline 4. & Umput candi & 87,61 & 21,05 & 10,69 & 0,73 & 17,42 & 3101 \\
\hline 5. & Umput bento & 92,15 & 19,90 & 18,24 & 0,31 & 30,56 & 3428 \\
\hline 6. & Umput kudo & 91,10 & 12,23 & 12,97 & 1,13 & 50,05 & 3683 \\
\hline 7. & Seting & 90,93 & 8,37 & 33,86 & 0,97 & 9,13 & 4250 \\
\hline 8. & Cabe keriting & 89,65 & 12,31 & 31,11 & 0,82 & 12,69 & 4112 \\
\hline 9. & Jeluang & 89,98 & 9,42 & 13,22 & 0,72 & 13,73 & 4369 \\
\hline 10. & Capu angin & 90,12 & 16,70 & 31,13 & 0,93 & 8,25 & 3911 \\
\hline 11. & Kayu asam & 91,12 & 12,45 & 7,17 & 0,90 & 28,03 & 3952 \\
\hline 12. & Inai rimbo & 90,10 & 10,09 & 10,52 & 1,50 & 16,38 & 3873 \\
\hline & Umbut : & & & & & & \\
\hline 13. & Lolo ayam & 88,77 & 7,11 & 17,97 & 1,15 & 11,65 & 4103 \\
\hline & Buah : & & & & & & \\
\hline 14. & Asam kandi & 76,4 & 1,93 & 2,36 & $*)$ & $*)$ & *) \\
\hline 15. & Kayu nasi & 86,5 & 14,55 & 13,66 & $*)$ & *) & $*)$ \\
\hline 16. & Akar gitan & 87,78 & 10,55 & 8,36 & 3,34 & 35,07 & 3721 \\
\hline 17. & Jambu arang & 78,09 & 2,59 & 5,64 & $*)$ & $*)$ & $*)$ \\
\hline 18. & Aka & 84,47 & 5,28 & 8,33 & 1,22 & 27,14 & 3946 \\
\hline 19. & Bunga dayung & 89,62 & 4,03 & 11,80 & 5,29 & 12,22 & 4548 \\
\hline
\end{tabular}

*) Sampel tidak cukup 


\section{Kesimpulan}

Hampir di semua lokasi yang terjelajah tersebar habitat tapir, sedangkan kijang lebih menyukai habitat hutan dan di semak-semak pinggiran hutan. Habitat kukang lebih banyak di wilayah hutan yang lebih rendah baik di dalam dan di luar kawasan Taman Nasional Kerinci Seblat. Tercatat 38 jenis yang tergolong ke dalam 25 suku tumbuhan hutan sebagai sumber pakan tapir, kijang, dan kukang. 12 jenis tumbuhan yang dipilih baik oleh kijang dan tapir sebagai sumber pakannya, dan hanya 1 jenis tumbuhan yang dimakan kijang, 6 jenis tumbuhan yang dimakan oleh tapir, 4 jenis tumbuhan dimakan baik oleh tapir juga kukang, 14 jenis tumbuhan dimakan oleh kukang, dan hanya 1 jenis tumbuhan yang dimakan baik oleh kijang, tapir, maupun kukang. Tapir dan kijang lebih banyak memilih pakan jenis dedaunan, sedangkan kukang lebih banyak memakan jenis buah-buahan.

\section{Ucapan Terima Kasih}

Tim peneliti mengucapkan terima kasih kepada Balai Taman Nasional Kerinci Seblat (TNKS), Jambi atas izin penelitian yang diberikan. Kepada Staf dan Polisi Hutan TNKS yang telah banyak membantu selama penelitian, kami ucapkan terima kasih.

\section{Daftar Pustaka}

Anonimous. 1996. List of CITES Species. Direktorat Jenderal Perlindungan Hutan dan Pelestarian Alam. Departemen Kehutanan, Jakarta.
Blouch, R. A. 1984. Current status of the Sumatera rhino and Other Large Mammals in Southern Sumatera. A WWF Report., 4, Bogor, Indonesia.

Farida, W.R., G. Semiadi, T.H. Handayani, dan Harun. 2002. Habitat distribution and diversity of plants as feed resources on mouse deer (Tragulus javanicus) and barking deer (Muntiacus muntjak) in Gunung Halimun National Park. Proceeding of International Symposium on Land Management and Biodiversity in Southeast Asia. Bali, 18 to 20 September 2002.

Harris, L.E. $1970 . \quad$ Nutrition Research Techniques for Domestic and Wild Animals. Animal Science Department, Utah State University, Logan.

Lekagul, B. and J.A. McNeely. 1977. Mammals of Thailand. The Association for the Conservation of Wildlife, Bangkok.

Mac Kinnon, K. 1984. Tapirs. In : The Encyclopaedia of Mammals (D.Macdonald, Ed.) Vol 1 : 488489. George Allen and Unwin, Toronto.

Napier, J.R. and P.H. Napier. 1967. A Handbook of Living Primates. Academic Press. London.

Semiadi, G. 1998. Budidaya Rusa Tropika sebagai Hewan Ternak. Masyarakat Zoologi Indonesia. Bogor. 
Supriatna, J dan E. H. Wahyono.

2000. Panduan Lapangan

Primata Indonesia. Yayasan

Obor Indonesia, Jakarta.

Thohari, M. $1987 . \quad$ Upaya Penangkaran Satwa Liar. Media Konservasi 1 (3): 10-16.

Wirdateti, L.E. Setyorini, Suparno dan Tri Hadiyani. 2002. Pengamatan Pakan Kukang (Nycticebus coucang) di Hutan Lindung Baduy-Rangkas Bitung, Banten Selatan. Laporan Teknik Tahun 2002 Puslit Biologi LIPI.

Williams, K.D. 1980. Browse use, Feeding Behaviour, and Management of the Malayan Tapir. J. Wildl. Manage. 44: 489-494.

Yasuma, S dan H. S. Alikodra. 1990. Mammals of Bukit Soeharto Protection Forest. The Tropical Rain Forest Research Project. Samarinda, Kalimantan Timur. Indonesia.

Alamat korespondensi: W. Rosa Farida

Staf Peneliti pada Bidang Zoologi, Pusat Penelitian Biologi - LIPI, Cibinong-Bogor.

Artikel diterima: 27 Januari 2004, Disetujui: 20 Desember 2004 